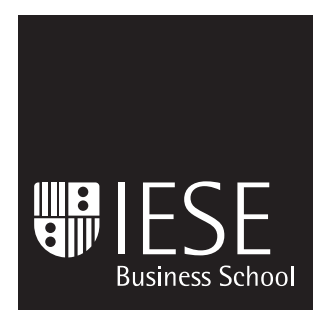

Working Paper

WP no 628

CIIF

May, 2006

University of Navarra

\title{
THE CORRECT VALUE OF TAX SHIELDS: AN ANALYSIS OF 23 THEORIES
}

\author{
Pablo Fernández
}

IESE Business School - Universidad de Navarra

Avda. Pearson, 21 - 08034 Barcelona, Spain. Tel.: (+34) 932534200 Fax: (+34) 932534343

Camino del Cerro del Águila, 3 (Ctra. de Castilla, km 5,180) - 28023 Madrid, Spain. Tel.: (+34) 913570809 Fax: (+34) 913572913

Copyright ${ }^{\odot} 2006$ IESE Business School. 
The CIIF, International Center for Financial Research, is an interdisciplinary center with an international outlook and a focus on teaching and research in finance. It was created at the beginning of 1992 to channel the financial research interests of a multidisciplinary group of professors at IESE Business School and has established itself as a nucleus of study within the School's activities.

Ten years on, our chief objectives remain the same:

- Find answers to the questions that confront the owners and managers of finance companies and the financial directors of all kinds of companies in the performance of their duties

- Develop new tools for financial management

- Study in depth the changes that occur in the market and their effects on the financial dimension of business activity

All of these activities are programmed and carried out with the support of our sponsoring companies. Apart from providing vital financial assistance, our sponsors also help to define the Center's research projects, ensuring their practical relevance.

The companies in question, to which we reiterate our thanks, are:

Aena, A.T. Kearney, Caja Madrid, Fundación Ramón Areces, Grupo Endesa, Royal Bank of Scotland and Unión Fenosa.

http://www.iese.edu/ciif/ 


\title{
THE CORRECT VALUE OF TAX SHIELDS: AN ANALYSIS OF 23 THEORIES
}

\author{
Pablo Fernández*
}

\section{Abstract}

This paper provides guidelines for evaluating the appropriateness of 23 different valuation methods for estimating the present value of tax shields.

We first show that the value of tax shields is the difference between the present values of two different cash flows with their own risks: the present value of taxes for the unleveraged company and the present value of taxes for the leveraged company. This implies, as a first guideline, that for the particular case of a perpetuity and a world without costs of leverage, the value of tax shields is equal to the tax rate times the value of debt. The value of tax shields can be lower when costs of leverage exist. In that case, we show that, since the existence of leverage costs is independent of taxes, a second guideline for the appropriateness of the valuation method should be that the value of tax shields when there are no taxes is negative. We then look at the case of constant growth and derive similar conclusions.

Second, we identify 23 valuation theories proposed in the literature to estimate the present value of tax shields and illustrate their performance relative to the proposed guidelines. Eight of these theories do not satisfy the two proposed guidelines for the case of perpetuities. Only one of the valuation methods is consistent with these restrictions when we look at the case of constant growth and no leverage costs. Two theories provide consistent valuations when we allow for leverage costs and growth.

Finally, we use the 23 theories to value a hypothetical firm and show the remarkable differences in the values obtained, which demonstrates the importance of using a method consistent with the proposed guidelines.

* Professor of Financial Management, PricewaterhouseCoopers Chair of Finance, IESE

JEL Classification: G12, G31, M21

Keywords: Value of Tax Shields; Valuation Theories; Valuation Methods 


\section{THE CORRECT VALUE OF TAX SHIELDS. AN ANALYSIS OF 23 THEORIES}

\section{Introduction}

Although Copeland et al. (2000) claim that "the finance literature does not provide a clear answer about which discount rate for the tax benefit of interest is theoretically correct," we show that we can provide some clear answers on this topic.

First, following a new method, we prove that the value of tax shields for perpetuities in a world without costs of leverage is equal to the tax rate times the value of debt (DT). The result we get is the same as in Modigliani-Miller (1963), but the reasoning behind it and the implications involved are quite different. The increase in the company's value due to the use of debt is not the present value of the tax shield due to interest payments. It is the difference between the present value of the taxes of the unleveraged company and the present value of the taxes of the leveraged company, which are the present values of two separate cash flows each with their own risk. The issue of the degree of risk of the taxes for both the unleveraged and the leveraged company is addressed. We prove that, in perpetuities, the required return on tax in the unleveraged company is equal to the required return on equity in the unleveraged company. It is also proven that the required return on tax in the leveraged company is equal to the required return on equity.

The value of tax shields is not the present value of tax shields due to the payment of interest but the difference between Gu and GL, which are the present values of two cash flows with different risks.

Second, we analyze 23 theories proposed in the literature about the increase in the company's value due to the use of debt.

By analyzing perpetuities, we are able to eliminate eight theories that neither provide us with a value of the tax shield of DT (as the candidates for a world with no leverage costs should), nor provide us with a negative value of tax shields (VTS) when there are no taxes (as the candidates for a world with leverage costs should). The eight candidates eliminated due to a lack of consistent results are the following: Harris-Pringle (1985) or Ruback (1995); Miles-Ezzell (1980), F 1, F 2, F 8 , F 9, F 10; and Miller (1977).

By analyzing constant growth companies, we are able to see that there is but one theory that provides consistent results in a world without leverage costs. In accordance with this theory, the

\footnotetext{
${ }^{1}$ I would like to thank my colleague José Manuel Campa for his very helpful comments and Charlie Porter for his wonderful help revising previous manuscripts of this paper. 
VTS is the present value of DTKu discounted at the unleveraged cost of equity $(\mathrm{Ku})$. It is not the interest tax shield that is discounted.

We find two theories that provide consistent results in a world with leverage costs, but both introduce leverage costs in an ad hoc way. The differences between the theories can be attributed to the leverage costs implied by each of them. The finance literature tells us very little about how to calculate costs of leverage and how the magnitude of debt, the type of debt, taxes and other factors influence them. There is a need for further research on this area.

Third, we value a company following all 23 theories and the variation in the results is remarkable.

Appendix 1 contains a glossary of the acronyons used in the paper.

The most important issue to bear in mind when reading this paper is that the term "discounted value of tax shields" in itself is meaningless. The value of tax shields is the difference between two present values of two separate cash flows each with its own risk.

\section{Literature Review}

There is a considerable body of literature on the discounted cash flow valuation of firms. We will discuss here the most salient papers, concentrating particularly on those which propose different expressions for the present value of the tax savings due to the payment of interest or value of tax shields (VTS).

According to the No-costs-of-leverage theory, the VTS is the present value of D T Ku (not the interest tax shield) discounted at the unleveraged cost of equity (Ku): PV[Ku; D T Ku]. We label this theory No-cost-of-leverage because it is the only consistent theory, as will be seen in Section 6 .

This theory implies that the relationship between the leveraged beta and the unleveraged beta is

$$
\beta_{\mathrm{L}}=\beta \mathrm{u}+\frac{\mathrm{D}(1-\mathrm{T})}{\mathrm{E}}(\beta \mathrm{u}-\beta \mathrm{d})
$$

Modigliani and Miller (1958) studied the effect of leverage on the firm's value. Their proposition 1 (1958, formula 3) states that, in the absence of taxes, the firm's value is independent of its debt, i.e., $\mathrm{E}+\mathrm{D}=\mathrm{Vu}$, if $\mathrm{T}=0$.

$\mathrm{E}$ is the equity value, $\mathrm{D}$ is the debt value, $\mathrm{Vu}$ is the value of the unleveraged company and $\mathrm{T}$ is the tax rate.

In the presence of taxes, their second proposition (1963, formula 12.c) states that the required return on equity flows $(\mathrm{Ke})$ increases at a rate that is directly proportional to the debt to equity ratio $(\mathrm{D} / \mathrm{E})$ at market value: $\mathrm{Ke}=\mathrm{Ku}+(\mathrm{D} / \mathrm{E})(1-\mathrm{T})(\mathrm{Ku}-\mathrm{Kd})$.

In the presence of taxes and for the case of a perpetuity, their first proposition is transformed into (1963, formula 3): 


$$
\mathrm{E}_{0}+\mathrm{D}_{0}=\mathrm{V}_{\mathrm{u}}+\mathrm{DT}
$$

DT is the value of tax shields (VTS) for a perpetuity. But it is important to note that they arrive at the value of tax shields (VTS) by discounting the present value of the tax savings due to interest payments of a risk free debt (T D RF) at the risk free rate (RF).

As we will prove later on, although the result is correct, to discount the tax savings due to interest payments of a risk free debt at the risk free rate provides inconsistent results for growing companies.

Modigliani and Miller aim to illustrate the tax impact of debt on value. They only deal with perpetuities. Equations [1] and [2] were derived for level perpetuities.

They also state in their paper (1963, formula 33.c) that, in an investment that can be financed totally by debt, the required return on the debt must be equal to the required return on the asset flows: if $\mathrm{D} /(\mathrm{D}+\mathrm{E})=100 \%, \mathrm{Kd}=\mathrm{Ku}$.

Myers (1974) introduces the APV (adjusted present value). According to Myers, the value of the leveraged firm is equal to the value of the firm with no debt $(\mathrm{Vu})$ plus the present value of the tax saving due to the payment of interest (VTS). Myers proposes calculating the VTS in the following manner:

$$
\mathrm{VTS}=\mathrm{PV}[\mathrm{Kd} ; \mathrm{D} \mathrm{T} \mathrm{Kd}]
$$

According to Myers (1974), the value creation of the tax shield is the present value of the interest tax shield discounted at the cost of debt $(\mathrm{Kd})$. The argument is that the risk of the tax saving arising from the use of debt is the same as the risk of the debt. Luehrman (1997) recommends valuing companies using adjusted present value and he calculates the VTS as Myers does. We will see later on that this theory provides inconsistent results.

Miller (1977) assumes no advantages to debt financing: "I argue that even in a world in which interest payments are fully deductible in computing corporate income taxes, the value of the firm, in equilibrium, will still be independent of its capital structure." Miller assumes that VTS $=0$.

According to Miles and Ezzell (1980), a firm that wishes to keep a constant D/E ratio must be valued in a different manner from the firm that has a preset level of debt. For a firm with a fixed debt target $[\mathrm{D} /(\mathrm{D}+\mathrm{E})]$ they claim that the correct rate for discounting the tax saving due to debt (Kd $\mathrm{T} \mathrm{Dt}-1$ ) is $\mathrm{Kd}$ for the tax saving during the first year, and $\mathrm{Ku}$ for the tax saving during the following years.

The expression of Ke is given in their formula [22]:

$$
\mathrm{Ke}=\mathrm{Ku}+\mathrm{D}(\mathrm{Ku}-\mathrm{Kd})[1+\mathrm{Kd}(1-\mathrm{T})] /[(1+\mathrm{Kd}) \mathrm{E}]
$$

Although Miles and Ezzell do not mention what the value of tax shields should be, their formula relating the required return on equity with the required return for the unleveraged company implies that

$$
\mathrm{VTS}=\mathrm{PV}[\mathrm{Ku} ; \mathrm{T} \mathrm{D} \mathrm{Kd}](1+\mathrm{Ku}) /\left(1+\mathrm{Kd}_{0}\right)
$$


For a firm with a fixed debt target $[D /(D+E)]$ they claim that the correct rate for discounting the tax saving due to debt (Kd T Dt-1) is $\mathrm{Kd}$ for the tax saving during the first year, and $\mathrm{Ku}$ for the tax saving during the following years.

Taggart (1991) gives a good summary of valuation formulas with and without personal income tax. He proposes that Miles \& Ezzell's (1980) formulas should be used when the company adjusts to its target debt ratio once a year, and Harris \& Pringle's (1985) formulas when the company continuously adjusts to its target debt ratio.

Lewellen and Emery (1986) propose three alternative ways of calculating the VTS. They claim that the most logically consistent is the method proposed by Miles and Ezzell.

Damodaran (1994, page 31) argues that if all the business risk is borne by the equity, then the formula relating the leveraged beta $\left(\beta_{\mathrm{L}}\right)$ to the asset beta $\left(\beta_{\mathrm{u}}\right)$ is:

$$
\beta_{\mathrm{L}}=\beta \mathrm{u}+\frac{\mathrm{D}(1-\mathrm{T})}{\mathrm{E}} \beta \mathrm{u}
$$

Although Damodaran does not mention what the value of tax shields should be, his formula relating the leveraged beta to the asset beta implies that

$$
\mathrm{VTS}=\mathrm{PV}\left[\mathrm{Ku} ; \mathrm{DTKu}-\mathrm{D}\left(\mathrm{Kd}-\mathrm{R}_{\mathrm{F}}\right)(1-\mathrm{T})\right]
$$

It is important to notice that formula [5] is exactly the same as formula [1] assuming that $\beta d=0$. Although one interpretation of this assumption is that "all of the firm's risk is borne by the stockholders (i.e., the beta of the debt is zero)," ${ }^{2}$ we think that it is difficult to justify that the return on the debt is uncorrelated with the return on assets of the firm. We rather interpret formula [5] as an attempt to introduce leverage costs into the valuation: for a given risk of the assets $(\beta u)$, by using formula [5] we obtain a higher L (and consequently a higher Ke and a lower equity value) than with formula [1].

Another way of calculating the leveraged beta with respect to the asset beta is the following:

$$
\beta_{\mathrm{L}}=\beta \mathrm{u}+\frac{\mathrm{D}}{\mathrm{E}} \beta \mathrm{u} \quad \text { implies that } \quad \mathrm{VTS}=\mathrm{PV}\left[\mathrm{Ku} \text {; T D Ku }-\mathrm{D}\left(\mathrm{Kd}-\mathrm{R}_{\mathrm{F}}\right)\right] \quad \text { [7] }
$$

We will call this method the Practitioners Method, because consultants and investment banks often use it. One of the many places where it appears is Ruback (1995, page 5). It is obvious that according to this formula, given the same value for $\beta \mathrm{u}$, a higher $\beta_{\mathrm{L}}$ is obtained than according to No-cost-of-leverage and Damodaran (1994). Formula [7] is exactly the same as formula [5], eliminating the (1-T) term. We interpret formula [7] as an attempt to introduce a still higher leverage cost into the valuation: for a given risk of the assets $\left(\beta_{u}\right)$, by using formula [7] we obtain a higher $\beta_{\mathrm{L}}$ (and consequently a higher Ke and a lower equity value) than with formula [5].

Inselbag and Kaufold (1997) argue that if the firm targets the dollar values of debt outstanding, the VTS is given by the Myers formula. However, if the firm targets a constant debt/value ratio, the VTS is given by the Miles and Ezzell formula.

Copeland, Koller and Murrin (2000) deal with adjusted present value in their Appendix A. They only mention perpetuities and propose only two ways of calculating the VTS: Harris and Pringle (1985) and Myers (1974). They conclude that "we leave it to the reader's judgment to decide which

\footnotetext{
${ }^{2}$ See page 31 of Damodaran (1994).
} 
approach best fits his or her situation." They also claim that "the finance literature does not provide a clear answer as to which discount rate for the tax benefit of interest is theoretically correct." Copeland et al (2000, page 483) only suggest Inselbag and Kaufold (1997) as additional reading on APV.

Harris and Pringle (1985) propose that the present value of the tax saving due to the payment of interest (VTS) should be calculated by discounting the tax saving due to the debt (Kd T D) at the rate $\mathrm{Ku}$ :

$$
\text { VTS }=\mathrm{PV}[\mathrm{Ku} ; \mathrm{D} \mathrm{Kd} \mathrm{T}]
$$

One straight interpretation of this assumption is that "the interest tax shields have the same systematic risk as the firm's underlying cash flows." 3 But another interpretation comes from analyzing the formula that relates the leveraged beta with the asset beta:

$$
\beta_{L}=\beta u+\frac{D}{E}(\beta u-\beta d)
$$

It is important to notice that formula [9] is exactly the same as formula [1] eliminating the (1-T) term. We may interpret formula [9] as an attempt to introduce still higher leverage costs into the valuation: for a given risk of the assets $(\beta u)$, by using formula [9] we obtain a higher $\beta_{\mathrm{L}}$ (and consequently a higher Ke and a lower equity value) than with formula [1].

They also propose in their formula (3) that $\mathrm{WACC}_{\mathrm{BT}}=\mathrm{Ku}$ and, therefore, their expression for WACC is:

$$
\mathrm{WACC}=\mathrm{Ku}-\mathrm{D} \mathrm{Kd} \mathrm{T} /(\mathrm{D}+\mathrm{E})
$$

$\mathrm{WACC}_{\mathrm{BT}}$ is the appropriate discount rate for the capital cash flow (the sum of the equity cash flow and debt cash flow).

Harris and Pringle (1985) say "the MM position is considered too extreme by some because it implies that interest tax shields are no more risky than the interest payments themselves. The Miller position is too extreme for some because it implies that debt cannot benefit the firm at all. Thus, if the truth about the value of tax shields lies somewhere between the MM and Miller positions, a supporter of either Harris and Pringle or Miles and Ezzell can take comfort in the fact that both produce a result for unleveraged returns between those of MM and Miller. A virtue of Harris and Pringle compared to Miles and Ezzell is its simplicity and straightforward intuitive explanation."

Ruback (1995) assumes in his formula (2.6) that $\beta_{\mathrm{L}}=\beta_{\mathrm{U}}(\mathrm{D}+\mathrm{E}) / \mathrm{E}-\beta_{\mathrm{D}} \mathrm{D} / \mathrm{E}$. With this assumption Ruback arrives at formulas that are identical to those of Harris-Pringle (1985). Kaplan and Ruback (1995) also calculate the VTS "discounting interest tax shields at the discount rate for an all-equity firm." Tham and Vélez-Pareja (2001), following an arbitrage argument, also claim that the appropriate discount rate for the tax shield is $\mathrm{Ku}$, the return on unleveraged equity. We will see in Section 4 that this theory provides inconsistent results.

Table 1 contains the 23 theories that we will analyze. For each theory, the table contains the formula for calculating the VTS and the equation that relates the required return on equity, Ke, with the required return on assets (or required return on unleveraged equity), Ku.

\footnotetext{
${ }^{3}$ Kaplan and Ruback (1995) 


\section{Table 1}

23 Competing Theories for Calculating the Value of Tax Shields

\begin{tabular}{|c|c|c|c|}
\hline & Theory & VTS & Ke \\
\hline 1 & No-cost-of-leverage & $\mathrm{PV}[\mathrm{Ku} ; \mathrm{D} \mathrm{T} \mathrm{Ku}]$ & $\mathrm{Ke}=\mathrm{Ku}+(\mathrm{D} / \mathrm{E})(1-\mathrm{T})(\mathrm{Ku}-\mathrm{Kd})$ \\
\hline 2 & Damodaran (1994) & $\mathrm{PV}\left[\mathrm{Ku} ; \mathrm{D} \mathrm{T} \mathrm{Ku}-\mathrm{D}\left(\mathrm{Kd}-\mathrm{R}_{\mathrm{F}}\right)(1-\mathrm{T})\right]$ & $\mathrm{Ke}=\mathrm{Ku}+(\mathrm{D} / \mathrm{E})(1-\mathrm{T})\left(\mathrm{Ku}-\mathrm{R}_{\mathrm{F}}\right)$ \\
\hline 3 & Practitioners & $\mathrm{PV}\left[\mathrm{Ku} ; \mathrm{T} \mathrm{D} \mathrm{Kd}-\mathrm{D}\left(\mathrm{Kd}-\mathrm{R}_{\mathrm{F}}\right)\right]$ & $K e=K u+(D / E)\left(K u-R_{F}\right)$ \\
\hline 4 & $\begin{array}{c}\text { Harris-Pringle } \\
\text { (1985), Ruback } \\
\text { (1995) }\end{array}$ & $\mathrm{PV}[\mathrm{Ku} ; \mathrm{T} \mathrm{D} \mathrm{Kd}]$ & $\mathrm{Ke}=\mathrm{Ku}+(\mathrm{D} / \mathrm{E})(\mathrm{Ku}-\mathrm{Kd})$ \\
\hline 5 & Myers (1974) & $\mathrm{PV}[\mathrm{Kd} ; \mathrm{T} \mathrm{D} \mathrm{Kd}]$ & $\mathrm{Ke}=\mathrm{Ku}+[(\mathrm{D}-\mathrm{VTS}) / \mathrm{E}](\mathrm{Ku}-\mathrm{Kd})$ \\
\hline 6 & Miles-Ezzell (1980) & $\mathrm{PV}[\mathrm{Ku} ; \mathrm{T} \mathrm{D} \mathrm{Kd}](1+\mathrm{Ku}) /\left(1+\mathrm{Kd}_{0}\right)$ & $\mathrm{Ke}=\mathrm{Ku}+\frac{\mathrm{D}}{\mathrm{E}}(\mathrm{Ku}-\mathrm{Kd})\left[1-\frac{\mathrm{T} \mathrm{Kd}}{1+\mathrm{Kd}}\right]$ \\
\hline 7 & Miller (1977) & 0 & $\mathrm{Ke}=\mathrm{Ku}+(\mathrm{D} / \mathrm{E})[\mathrm{Ku}-\mathrm{Kd}(1-\mathrm{T})]$ \\
\hline 8 & F 1 & $\mathrm{PV}\left[\mathrm{Ku} ; \mathrm{D} \mathrm{T}\left(\mathrm{Ku}-\mathrm{R}_{\mathrm{F}}\right)\right]$ & $\mathrm{Ke}=\mathrm{Ku}+\frac{\mathrm{D}}{\mathrm{E}}\left[(\mathrm{Ku}-\mathrm{Kd})(1-\mathrm{T})+\mathrm{TR}_{\mathrm{F}}\right]$ \\
\hline 9 & F 2 & $\mathrm{PV}[\mathrm{Ku} ; \mathrm{D} \mathrm{T}(\mathrm{Ku}-\mathrm{Kd})]$ & $\mathrm{Ke}=\mathrm{Ku}+\frac{\mathrm{D}}{\mathrm{E}}[(\mathrm{Ku}-\mathrm{Kd})(1-\mathrm{T})+\mathrm{TKd}]$ \\
\hline 10 & F 3 & $P V\left[K u ; D\left(K u T+R_{F}-K d\right)\right.$ & $\mathrm{Ke}=\mathrm{Ku}+\frac{\mathrm{D}}{\mathrm{E}}\left[\mathrm{Ku}(1-\mathrm{T})+\mathrm{KdT}-\mathrm{R}_{\mathrm{F}}\right]$ \\
\hline 11 & F 4 & $P V\left[K u ;-D\left(K u(1-T)-R_{F}\right)\right]$ & $K e=K u+\frac{D}{E}\left[K u+(K u-K d)(1-T)-R_{F}\right]$ \\
\hline 12 & F 5 & $\mathrm{PV}\left[\mathrm{Ku} ; \mathrm{D}\left(\mathrm{Ku}-\mathrm{Kd}(1-\mathrm{T})-\mathrm{R}_{\mathrm{F}}\right)\right]$ & $\mathrm{Ke}=\mathrm{Ku}+(\mathrm{D} / \mathrm{E}) \mathrm{R}_{\mathrm{F}}$ \\
\hline 13 & F 6 & $\mathrm{PV}[\mathrm{Ku} ; \mathrm{D} \mathrm{Ku}-\mathrm{D} \mathrm{Kd}(2-\mathrm{T})]$ & $\mathrm{Ke}=\mathrm{Ku}+(\mathrm{D} / \mathrm{E}) \mathrm{Kd}$ \\
\hline 14 & F 7 & $P V\left[R_{F} ; D\left(K d T-\left(K d-R_{F}\right)\right)\right]$ & $\mathrm{Ke}=\mathrm{Ku}+\frac{\mathrm{D}-\mathrm{DVTS}}{\mathrm{E}}\left[\mathrm{Ku}-\mathrm{R}_{\mathrm{F}}\right]$ \\
\hline 15 & F 8 & $\mathrm{PV}[\mathrm{Ke} ; \mathrm{D} \mathrm{Kd} \mathrm{T}]$ & $\mathrm{Ke}=\frac{\mathrm{VuKu}-\mathrm{DKd}}{\mathrm{Vu}-\mathrm{D}}$ \\
\hline 16 & F 9 & $\mathrm{PV}[(\mathrm{Ku}+\mathrm{Kd}) / 2 ; \mathrm{D} \mathrm{Kd} \mathrm{T}]$ & $\mathrm{Ke}=\mathrm{Ku}+\frac{2 \mathrm{D}-\mathrm{DVTS}}{2 \mathrm{E}}[\mathrm{Ku}-\mathrm{Kd}]$ \\
\hline 17 & F 10 & $P V\left[K u ; D T\left(K u+R_{F}-K d\right)\right]$ & $K e=K u+\frac{D}{E}\left[(K u-K d)(1-T)+T\left(K d-R_{F}\right)\right]$ \\
\hline 18 & F 11 & $\mathrm{PV}\left[\mathrm{Ku} ; \mathrm{D}\left[\mathrm{Ku}-\left(\mathrm{Kd}+\mathrm{R}_{\mathrm{F}}\right)(1-\mathrm{T})\right]\right]$ & $\mathrm{Ke}=\mathrm{Ku}+(\mathrm{D} / \mathrm{E}) \mathrm{R}_{\mathrm{F}}(1-\mathrm{T})$ \\
\hline 19 & F 12 & $\mathrm{PV}[\mathrm{Ku} ; \mathrm{D}[\mathrm{Ku}-2 \mathrm{Kd}(1-\mathrm{T})]$ & $\mathrm{Ke}=\mathrm{Ku}+(\mathrm{D} / \mathrm{E}) \mathrm{Kd}(1-\mathrm{T})$ \\
\hline 20 & F 13 & $\mathrm{PV}[\mathrm{Ke} ; \mathrm{D} \mathrm{T} \mathrm{Ke}]$ & $\mathrm{Ke}=\mathrm{Ku}+\frac{\mathrm{D}(1-\mathrm{T})}{\mathrm{Vu}-\mathrm{D}(1-\mathrm{T})}(\mathrm{Ku}-\mathrm{Kd})$ \\
\hline 21 & F 14 & PV[WACC; D T WACC] & $\mathrm{Ke}=\mathrm{Ku}+\frac{\mathrm{D}}{\mathrm{E}}\left[\frac{\mathrm{Ku}(\mathrm{Vu}-\mathrm{ET})}{\mathrm{DT}+\mathrm{Vu}}-\mathrm{Kd}(1-\mathrm{T})\right]$ \\
\hline 22 & F 15 & $P V\left[W_{A C C}\right.$ BT $;$ D T WACC $\left.C_{\text {BT }}\right]$ & $\mathrm{Ke}=\mathrm{Ku}+\frac{\mathrm{D}}{\mathrm{E}} \frac{\mathrm{Vu}-\mathrm{ET}}{\mathrm{Vu}+\mathrm{DT}}(\mathrm{Ku}-\mathrm{Kd})$ \\
\hline 23 & Modigliani-Miller & $\mathrm{PV}\left[\mathrm{R}_{\mathrm{F}} ; \mathrm{D} T \mathrm{R}_{\mathrm{F}}\right]$ & $\mathrm{Ke}=\mathrm{Ku}+\frac{\mathrm{D}}{\mathrm{E}}\left[\mathrm{Ku}-\mathrm{Kd}(1-\mathrm{T})-(\mathrm{Ku}-\mathrm{g}) \frac{\mathrm{DVTS}}{\mathrm{D}}\right] *$ \\
\hline
\end{tabular}

* Valid only for growing perpetuities

$\mathrm{PV}=$ Present value; $\mathrm{T}=$ Corporate tax rate; $\mathrm{Ku}=$ Cost of unleveraged equity (required return of unleveraged equity); $\mathrm{Ke}=\mathrm{Cost}$ of leveraged equity (required return of leveraged equity); $\mathrm{Kd}=$ Required return on debt $=$ cost of debt; $\mathrm{D}=\mathrm{Value}$ of debt; $\mathrm{E}=\mathrm{Value}$ of equity; $R_{F}=$ Risk free rate; $W A C C=$ weighted average cost of capital. 
We have developed 15 additional formulas for valuing companies by cash flow discounting. Formulas 8 to 22 contain the expression for the VTS that applies in each of them.

F 1 to $\mathrm{F} 4$ introduce leverage costs into the valuation in different ways.

F 1 quantifies the leverage cost (assuming that No-cost-of-leverage provides the VTS without leverage costs) as $\mathrm{PV}\left[\mathrm{Ku}\right.$; $\left.\mathrm{D} \mathrm{T} \mathrm{R} \mathrm{R}_{\mathrm{F}}\right]$.

F 2 quantifies the leverage cost as PV[Ku; D T Kd].

F 3 quantifies the leverage cost as $\mathrm{PV}\left[\mathrm{Ku}\right.$; $\left.\mathrm{D}\left(\mathrm{Kd}-\mathrm{R}_{\mathrm{F}}\right)\right]$. One way of interpreting this assumption is that the reduction in the value of the firm due to leverage is proportional to the amount of debt and to the difference of the required return on debt minus the risk free rate. The cost of leverage does not depend on the tax rate.

F 10 is similar to F 3, but considers that the leverage costs are also proportional to the tax rate.

F 4 quantifies the leverage cost as $\mathrm{PV}\left[\mathrm{Ku} ; \mathrm{D}\left(\mathrm{Ku}-\mathrm{R}_{\mathrm{F}}\right)\right]$.

F 5 is derived from considering $\mathrm{Ke}=\mathrm{Ku}+(\mathrm{D} / \mathrm{E}) \mathrm{R}_{\mathrm{F}}$.

F 6 is derived from considering $\mathrm{Ke}=\mathrm{Ku}+(\mathrm{D} / \mathrm{E}) \mathrm{Kd}$.

F 11 is derived from considering $\mathrm{Ke}=\mathrm{Ku}+(\mathrm{D} / \mathrm{E}) \mathrm{R}_{\mathrm{F}}(1-\mathrm{T})$.

F 12 is derived from considering $\mathrm{Ke}=\mathrm{Ku}+(\mathrm{D} / \mathrm{E}) \mathrm{Kd}(1-\mathrm{T})$.

F 7 derives from Myers. It assumes that it is not the full tax shield that creates value, but rather the tax shield minus $\mathrm{D}\left(\mathrm{Kd}-\mathrm{R}_{\mathrm{F}}\right)$, but calculates the present value using the risk free rate instead of the cost of debt.

F 8 considers that the appropriate discount rate for the tax shields is Ke; the required return on equity.

F 9 considers that the appropriate discount rate for the tax shields is the average of $\mathrm{Ku}$; the required return on equity in the leveraged firm, and $\mathrm{Kd}$, the cost of debt. This theory is halfway between Myers and Harris-Pringle.

F 13 to F 15 and Modigliani-Miller accomplish the condition that for a perpetuity without leverage costs, the VTS is DT. For a perpetuity, DT $=$ D $\alpha \mathrm{T} / \alpha$. $\alpha$ may be anything, related or unrelated to the company that we are valuing. F 13 assumes that $\alpha$ is the required return on equity (Ke). F 14 assumes that $\alpha$ is the weighted average cost of capital (WACC). F 15 assumes that $\alpha$ is the weighted average cost of capital before taxes $\left(\mathrm{WACC}_{\mathrm{BT}}\right)^{4}$. Modigliani-Miller assumes that $\alpha$ is the risk-free rate $\left(\mathrm{R}_{\mathrm{F}}\right)$.

According to Modigliani and Miller (1963) the value of tax shields (VTS) for a perpetuity in the presence of taxes is DT (1963, formula 3). But it is important to note that they arrive at the value of tax shields (VTS) by discounting the present value of the tax savings due to interest payments of a risk free debt $\left(T D R_{F}\right)$ at the risk free rate $\left(R_{F}\right)$.

\footnotetext{
${ }^{4}$ For a company financed only with debt and equity, and if the required return on debt is equal to the cost of debt, the weighted average cost of capital is WACC $=[\mathrm{E} \mathrm{Ke}+\mathrm{D} \mathrm{Kd}(1-\mathrm{T})] /(\mathrm{E}+\mathrm{D})$. The weighted average cost of capital before taxes is: $\mathrm{WACC}_{\mathrm{BT}}=[\mathrm{E} \mathrm{Ke}+\mathrm{D} \mathrm{Kd}] /(\mathrm{E}+\mathrm{D})$. See Fernandez (2001b).
} 


\section{The Value of Tax Shields for Perpetuities in a World Without Leverage Costs Is DT}

It is assumed that the debt's market value (D) is equal to its book value (N). This means that the required return on debt $(\mathrm{Kd})$ is the same as the interest rate paid by the debt $(\mathrm{r})$.

The formula for the adjusted present value [11] indicates that the value of the debt today (D) plus that of the equity (E) of the leveraged company is equal to the value of the equity of the unleveraged company $(\mathrm{Vu})$ plus the value of tax shields due to interest payments (VTS).

$$
\mathrm{E}+\mathrm{D}=\mathrm{Vu}+\mathrm{VTS}
$$

VTS is the term used to define the increase in the company's value as a result of the tax saving obtained by the payment of interest (value of tax shield). For perpetuities $\mathrm{Vu}=\mathrm{FCF} / \mathrm{Ku}$.

In a world without leverage costs, the following relationship holds:

$$
\mathrm{Vu}+\mathrm{Gu}=\mathrm{E}+\mathrm{D}+\mathrm{GL}
$$

$\mathrm{Vu}$ is the value of the unleveraged company. $\mathrm{Gu}$ is the present value of the taxes paid by the unleveraged company. E is the equity value and D is the debt value. GL is the present value of the taxes paid by the leveraged company. Equation [12] means that the total value of the unleveraged company (left hand side of the equation) is equal to the total value of the leveraged company (right hand side of the equation). Total value is the enterprise value (often called value of the firm) plus the present value of taxes.

From [11] and [12], it is clear that the VTS (value of tax shields) is:

$$
\mathrm{VTS}=\mathrm{Gu}-\mathrm{GL}
$$

We should note that the value of tax shields (VTS) is not (as most theories and papers on this topic assume) the present value (PV) of tax shields. It is the difference between two PVs of two flows with different risks: the PV of the taxes paid in the unleveraged company $(\mathrm{Gu})$ and the PV of the taxes paid in the leveraged company (GL).

In a perpetuity, the profit after tax (PAT) is equal to the equity cash flow (ECF):

$$
\mathrm{PAT}=\mathrm{ECF}
$$

This is because in a perpetuity, depreciation must be equal to reinvestment in order to keep the cash flow generation capacity constant.

In a perpetuity, the free cash flow (FCF) is equal to the profit before tax of the unleveraged company $(\mathrm{PBTu})$ multiplied by $(1-\mathrm{T}), \mathrm{T}$ being the tax rate.

$$
\mathrm{FCF}=\mathrm{PBTu}(1-\mathrm{T})
$$

We will call the company's free cash flow if there were no taxes $\mathrm{FCF}_{0}$. The $\mathrm{FCF}_{0}$ is equal to the profit before taxes of the unleveraged company (PBTu).

$$
\mathrm{FCF}_{0}=\mathrm{PBTu}
$$


From [15] and [16] it is clear that:

$$
\mathrm{FCF}=\mathrm{FCF0}(1-\mathrm{T})
$$

For the unleveraged company $(\mathrm{D}=0)$ :

$$
\operatorname{Taxes}_{\mathrm{U}}=\mathrm{T} \text { PBTu }=\mathrm{T} \mathrm{FCF}_{0}=\mathrm{T} \mathrm{FCF} /(1-\mathrm{T})
$$

The taxes of the unleveraged company are proportional to $\mathrm{FCF}_{0}$ and FCF. Consequently, the taxes of the unleveraged company have the same risk as $\mathrm{FCF}_{0}$ (and FCF), and must be discounted at the $\mathrm{Ku}$ rate. The required return on tax in the unleveraged company $\left(\mathrm{K}_{\mathrm{TU}}\right)$ is equal to the required return on equity in the unleveraged company $(\mathrm{Ku})$. This is only true for perpetuities.

$$
\mathrm{K}_{\mathrm{TU}}=\mathrm{Ku}
$$

The present value of the taxes of the unleveraged company is:

$$
\mathrm{G}_{\mathrm{U}}=\mathrm{T} \mathrm{FCF} /[(1-\mathrm{T}) \mathrm{Ku}]=\mathrm{T} \mathrm{Vu} /(1-\mathrm{T})
$$

For the leveraged company it is:

$$
\operatorname{Taxes}_{\mathrm{L}}=\mathrm{TPBT}_{\mathrm{L}}=\mathrm{TPAT}_{\mathrm{L}} /(1-\mathrm{T})=\mathrm{T} \text { ECF } /(1-\mathrm{T})
$$

Consequently, in the case of perpetuities, the taxes of the leveraged company have the same risks as the ECF and must be discounted at the Ke rate. Thus, the tax risk is identical to the equity cash flow risk and - consequently - the required return on tax in the leveraged company $\left(\mathrm{K}_{\mathrm{TL}}\right)$ is equal to the required return on equity (Ke). This is only true for perpetuities.

$$
\mathrm{K}_{\mathrm{TL}}=\mathrm{Ke}
$$

The relationship between profit after tax (PAT) and profit before tax (PBT) is: PAT = PBT $(1-\mathrm{T})$.

The present value of the taxes of the leveraged company, that is, the value of the taxes paid to the government is:

$$
\mathrm{G}_{\mathrm{L}}=\mathrm{T} \mathrm{ECF} /[(1-\mathrm{T}) \mathrm{Ke}]=\mathrm{T} \mathrm{E} /(1-\mathrm{T})
$$

The increase in the company's value due to the use of debt is not the present value of the tax shield due to interest payments, but the difference between $G_{U}$ and $G_{L}$, which are the present values of two cash flows with different risks:

$$
\mathrm{VTS}=\mathrm{GU}-\mathrm{GL}=[\mathrm{T} /(1-\mathrm{T})](\mathrm{Vu}-\mathrm{E})
$$

As $\mathrm{Vu}-\mathrm{E}=\mathrm{D}-\mathrm{VTS}$, this gives:

$$
\text { VTS }=\text { Value of tax shields }=\text { DT }
$$

One problem with equation [25] is that DT can be understood as D $\alpha \mathrm{T} / \alpha$. At first glance, $\alpha$ can be anything related or unrelated to the company that we are valuing. Modigliani and Miller (1963) assume that $\alpha$ is the risk-free rate $\left(\mathrm{R}_{\mathrm{F}}\right)$. Myers (1974) assumes that $\alpha$ is the cost of debt (Kd) and says that the value of tax shields is the present value of the tax savings (D T Kd) discounted at the cost of debt $(\mathrm{Kd})$. But it has been shown that the value of tax shields is the difference between $\mathrm{Gu}$ and $G_{L}$, which are the present values of two cash flows with different risks: the taxes paid by the unleveraged company and the taxes paid by the leveraged company. In Section 7 we prove that the correct $\alpha$ is the required return on unleveraged equity $(\mathrm{Ku})$. 
This result is far from new. Brealey and Myers (2000), Modigliani and Miller (1963), Taggart (1991), Copeland et al. (2000) and many others report it. However, the way of deriving it is new.

\section{Analysis of the 23 Theories for Perpetuities}

Table 2 reports the implications of each of the 23 theories for the case of perpetuities. Column [1] contains the formula for calculating the VTS for perpetuities according to the 23 theories when the tax rate is positive. Column [2] contains the formula for calculating the VTS for perpetuities according to the 23 theories when there are no taxes.

It may be seen that only six theories accomplish formula [15], which implies VTS $=$ DT. The six theories are: No-cost-of-leverage, Myers, F 13, F 14, F 15 and Modigliani-Miller.

\section{Table 2}

Perpetuities. Value of Tax Shields (VTS) According to the 23 Theories

\begin{tabular}{|c|c|c|c|}
\hline & & \multicolumn{2}{|c|}{ VTS in Perpetuities } \\
\hline Theory & & $\mathrm{T}>0$ & $\mathrm{~T}=\mathbf{0}$ \\
\hline & & [2] & [3] \\
\hline 1 & No-cost-of-leverage & DT & 0 \\
\hline 2 & Damodaran & $\mathrm{DT}-\left[\mathrm{D}\left(\mathrm{Kd}-\mathrm{R}_{\mathrm{F}}\right)(1-\mathrm{T})\right] / \mathrm{Ku}<\mathrm{DT}$ & $-\mathrm{D}\left(\mathrm{Kd}-\mathrm{R}_{\mathrm{F}}\right) / \mathrm{Ku}<0$ \\
\hline 3 & Practitioners & $\mathrm{D}\left[\mathrm{R}_{\mathrm{F}}-\mathrm{Kd}(1-\mathrm{T})\right] / \mathrm{Ku}<\mathrm{DT}$ & $-\mathrm{D}\left(\mathrm{Kd}-\mathrm{R}_{\mathrm{F}}\right) / \mathrm{Ku}<0$ \\
\hline 4 & Harris-Pringle & $\mathrm{T} \mathrm{D} \mathrm{Kd/Ku<DT}$ & 0 \\
\hline 5 & Myers & DT & 0 \\
\hline 6 & Miles-Ezzell & $\operatorname{TDKd}(1+\mathrm{Ku}) /\left[\left(1+\mathrm{Kd}_{0}\right) \mathrm{Ku}\right]<\mathrm{DT}$ & 0 \\
\hline 7 & Miller (1977) & 0 & 0 \\
\hline 8 & F 1 & $\mathrm{DT}\left(\mathrm{Ku}-\mathrm{R}_{\mathrm{F}}\right) / \mathrm{Ku}<\mathrm{DT}$ & 0 \\
\hline 9 & $\mathrm{~F} 2$ & DT $(\mathrm{Ku}-\mathrm{Kd}) / \mathrm{Ku}<\mathrm{DT}$ & 0 \\
\hline 10 & F 3 & $\mathrm{D}\left(\mathrm{KuT}+\mathrm{R}_{\mathrm{F}^{-}} \mathrm{Kd}\right) / \mathrm{Ku}<\mathrm{DT}$ & $-\mathrm{D}\left(\mathrm{Kd}-\mathrm{R}_{\mathrm{F}}\right) / \mathrm{Ku}<0$ \\
\hline 11 & F 4 & $\mathrm{D}\left[\mathrm{R}_{\mathrm{F}}-\mathrm{Ku}(1-\mathrm{T})\right] / \mathrm{Ku}<\mathrm{DT}$ & $\mathrm{D}\left(\mathrm{R}_{\mathrm{F}}-\mathrm{Ku}\right) / \mathrm{Ku}<0$ \\
\hline 12 & F 5 & $\mathrm{D}\left[\mathrm{Ku}-\mathrm{Kd}(1-\mathrm{T})-\mathrm{R}_{\mathrm{F}}\right] / \mathrm{Ku}<\mathrm{DT} \stackrel{\circ}{\circ}$ & $\mathrm{D}\left[\mathrm{Ku}-\mathrm{Kd}-\mathrm{R}_{\mathrm{F}}\right] / \mathrm{Ku}<0^{*}$ \\
\hline 13 & F 6 & $\mathrm{D}[\mathrm{Ku}-\mathrm{Kd}(2-\mathrm{T})] / \mathrm{Ku}<\mathrm{DT} \cong 0$ & $\mathrm{D}(\mathrm{Ku}-2 \mathrm{Kd}) / \mathrm{Ku}<0^{* *}$ \\
\hline 14 & $\mathrm{~F} 7$ & $\mathrm{D}\left[\mathrm{KdT}-\left(\mathrm{Kd}-\mathrm{R}_{\mathrm{F}}\right)\right] / \mathrm{R}_{\mathrm{F}}<\mathrm{DT}$ & $-\mathrm{D}\left(\mathrm{Kd}-\mathrm{R}_{\mathrm{F}}\right) / \mathrm{R}_{\mathrm{F}}<0$ \\
\hline 15 & F 8 & $\mathrm{DKdT} / \mathrm{Ke}<\mathrm{DT}$ & 0 \\
\hline 16 & F9 & $2 \mathrm{DKdT} /(\mathrm{Ku}+\mathrm{Kd})<\mathrm{DT}$ & 0 \\
\hline 17 & F 10 & $\mathrm{DT}\left(\mathrm{Ku}+\mathrm{R}_{\mathrm{F}}-\mathrm{Kd}\right) / \mathrm{Ku}<\mathrm{DT}$ & 0 \\
\hline 18 & F 11 & $\mathrm{D}\left[\mathrm{Ku}-\left(\mathrm{Kd}+\mathrm{R}_{\mathrm{F}}\right)(1-\mathrm{T})\right] / \mathrm{Ku}<\mathrm{DT}^{*}$ & $\mathrm{D}\left(\mathrm{Ku}-\mathrm{Kd}-\mathrm{R}_{\mathrm{F}}\right) / \mathrm{Ku}<0^{*}$ \\
\hline 19 & F 12 & $\mathrm{D}[\mathrm{Ku}-2 \mathrm{Kd}(1-\mathrm{T})] / \mathrm{Ku}<\mathrm{DT} T^{\star *}$ & $\mathrm{D}(\mathrm{Ku}-2 \mathrm{Kd}) / \mathrm{Ku}<0^{* *}$ \\
\hline 20 & F 13 & DT & 0 \\
\hline 21 & F 14 & DT & 0 \\
\hline 22 & F 15 & DT & 0 \\
\hline 23 & Modigliani-Miller & DT & 0 \\
\hline
\end{tabular}




\begin{tabular}{|c|c|c|}
\cline { 2 - 3 } Necessary Conditions & With Leverage Costs & Without Leverage Costs \\
\hline $\mathbf{T}>\mathbf{0}$ & $<\mathrm{DT}$ & DT \\
\hline $\mathbf{T}=\mathbf{0}$ & $<0$ & 0 \\
\hline
\end{tabular}

\begin{tabular}{|l|l|l|}
\hline Number of Theories: & 9 & 6 \\
\hline & $\begin{array}{l}\text { Damodaran, Practitioners, F 3, F 4, F 5, F 6, F F } \\
7, \text { F 11, and F 12. }\end{array}$ & $\begin{array}{l}\text { No-cost-of-leverage, Myers, F 13, F 14, F 15 and } \\
\text { Modigliani-Miller. }\end{array}$ \\
\hline
\end{tabular}

Eight theories do not fulfill the necessary conditions to be considered: Harris-Pringle (1985) or Ruback (1995), Miles-Ezzell (1980), F 1, F 2, F 8, F 9, F 10, and Miller (1977).

The other 17 theories provide a VTS lower than DT. This difference could be attributed to the leverage cost. These 17 theories could be applicable in a "real world" where the leverage costs do exist. But if this was the case, leverage costs would also exist when there were no taxes. In this situation (column [3] of Table 2) these theories should provide a negative VTS. This is only the case in nine theories out of the 17: Damodaran, Practitioners, F 3, F 4, F 5, F 6, F 7, F 11, and F 12.

With these two conditions, we are able to eliminate eight theories that neither provide us with a value of the tax shield of DT (as the candidates for a world without leverage should), nor provide us with a negative VTS when there are no taxes (as the candidates for a world with leverage costs should). The eight candidates eliminated due to a lack of consistent results are the following: Harris-Pringle (1985) or Ruback (1995), Miles-Ezzell (1980), F 1, F 2, F 8, F 9, F 10, and Miller (1977).

The 23 candidate theories provide a value of VTS $=0$ if $\mathrm{D}=0$.

So far, we have eliminated 8 of the 23 theories.

\section{An Example of a Perpetuity}

A numerical example will help us to clarify the previous parameters. The cash flows generated by the company are perpetual and constant (there is no growth). The company must invest in order to maintain its assets at a level that enables it to ensure constant cash flows: this implies that the book depreciation is equal to the replacement investment.

\begin{tabular}{|lr|}
\hline Income statements and cash flows: \\
\hline Margin = PBTu & 800 \\
Interest paid (I) & $\underline{225}$ \\
Profit before tax (PBT) & 575 \\
Taxes (40\%) & $\underline{230}$ \\
Profit after tax (PAT) & 345 \\
+ Depreciation & 200 \\
- Investment in fixed assets & $\underline{-200}$ \\
ECF (Equity cash flow) & 345 \\
FCF (Free cash flow) & 480 \\
\hline
\end{tabular}

Debt $(D)=1,500 . \mathrm{Kd}=$ cost of debt $=$ required return on debt $=15 \%$. Equity book value $=800$.

$\mathrm{FCF}=\mathrm{ECF}+\mathrm{I}(1-\mathrm{T})=345+225(1-0.40)=480 . \mathrm{R}_{\mathrm{F}}=12 \% . \mathrm{Ku}=20 \%$.

Using equations [11] and [25], E $+\mathrm{D}=480 / 0.2+1,500 \times 0.4=3,000$. Equity market value $(\mathrm{E})=1,500$.

As $\mathrm{E}=\mathrm{ECF} / \mathrm{Ke}, \mathrm{Ke}=\mathrm{ECF} / \mathrm{E}=345 / 1,500=23 \%$

12 - IESE Business School-University of Navarra 
If we use the WACC (weighted average cost of capital), we obtain the same valuation:

$\mathrm{WACC}=[\mathrm{E} \mathrm{Ke}+\mathrm{D} \mathrm{Kd}(1-\mathrm{T})] /(\mathrm{E}+\mathrm{D})=[1,500 \times 0.23+1,500 \times 0.15 \times(1-0.4)] /(1,500+1,500)=16 \%$

$\mathrm{E}+\mathrm{D}=\mathrm{FCF} / \mathrm{WACC}=480 / 0.16=3,000$
[14] $\quad \mathrm{PAT}=\mathrm{ECF}=345$
[15] $\quad \mathrm{FCF}=\mathrm{PBTu}(1-\mathrm{T})=800 \times 0.6=480$
[16 $\quad \mathrm{FCF}_{0}=\mathrm{PBTu}=800$
[17] $\mathrm{FCF}=\mathrm{FCF}_{0}(1-\mathrm{T}) .480=800 \times 0.6$
[18] TaxesU $=\mathrm{T}$ PBTu $=\mathrm{T} \mathrm{FCF}_{0}=\mathrm{T}$ FCF $/(1-\mathrm{T})=320=0.4 \times 800=0.4 \times 480 / 0.6$
[19] $\mathrm{K}_{\mathrm{TU}}=\mathrm{Ku}=20 \%$
$[20] \mathrm{Gu}=\mathrm{T} \mathrm{FCF} /[(1-\mathrm{T}) \mathrm{Ku}]=\mathrm{T} \mathrm{Vu} /(1-\mathrm{T})=0.4 \times 480 /[0.6 \times 0.2]=1,600$
[21] $T$ TaxesL $=$ T PBTL $=$ T PATL $/(1-\mathrm{T})=\mathrm{T}$ ECF $/(1-\mathrm{T})=230$
[22] $\quad \mathrm{KTL}=\mathrm{Ke}=23 \%$
[23] $\mathrm{GL}=\mathrm{T} \mathrm{ECF} /[(1-\mathrm{T}) \mathrm{Ke}]=\mathrm{T} \mathrm{E} /(1-\mathrm{T})=0.4 \times 345 /[0.6 \times 0.23]=1,000$
[24] $\mathrm{VTS}=\mathrm{Gu}-\mathrm{GL}=1,600-1000=600$
[25] $\mathrm{VTS}=\mathrm{DT}=1,500 \times 0.4=600$

The value of the company can be seen in Figure 1. However, it is important to remember that by forcing fulfillment of the adjusted present value formula [25], we are accepting that the company's total value (debt, equity and tax) is independent of leverage, that is, there are no leverage-generated costs (there is no reduction in the expected FCF nor any increase in the company's risk).

It is important to note that the value of tax shields (VTS) is not (and this is the main error of many papers on this topic) the PV of the tax shield, but the difference between two PVs of two flows with different risks: the PV of the taxes paid in the unleveraged company $(\mathrm{Gu})$ and the PV of the taxes paid in the leveraged company $\left(\mathrm{G}_{\mathrm{L}}\right)$. Formula [25] (VTS = DT) is the difference between the two PVs. Obviously, the flow of taxes paid in the leveraged company is smaller and riskier than the flow of taxes paid in the unleveraged company.

\section{Figure 1}

Distribution of the Company's Total Value Between Shareholders, Bondholders and the Government. Without Leverage Costs

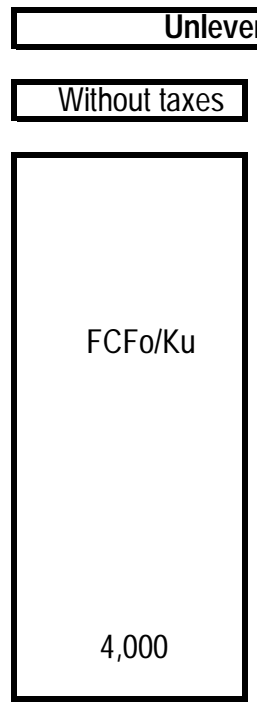

Unleveraged company

With taxes

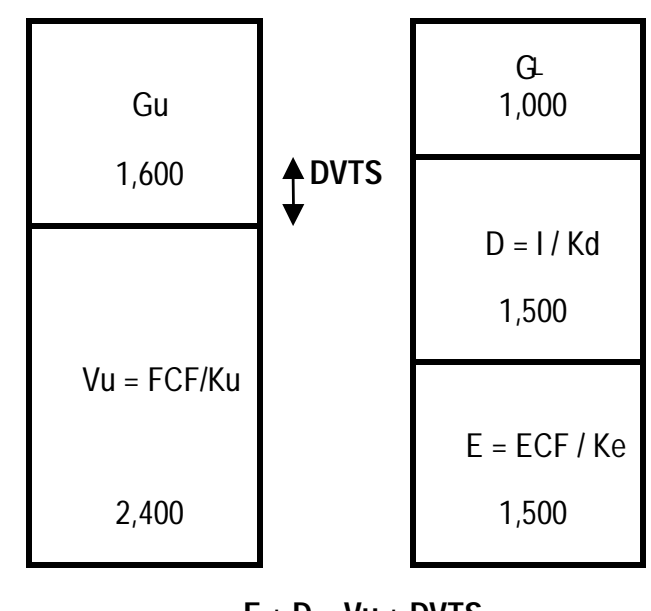

$E+D=V u+D V T S$
Leveraged company with taxes

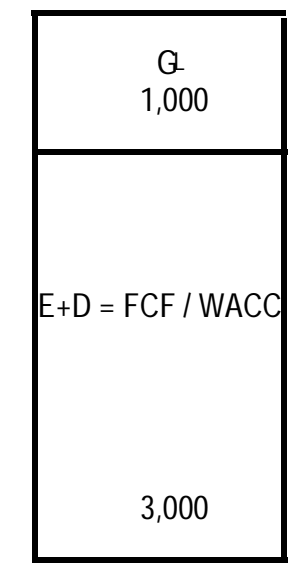

IESE Business School-University of Navarra - 13 
Table 3 represents the application of the 23 theories to perpetuities. Column [1] contains the formula for calculating the VTS for perpetuities according to the 23 theories. Column [2] contains the VTS of the previous example according to the 23 theories. Column [3] contains the VTS of the previous example according to the 23 theories if the tax rate were 0 .

It may be seen that only six theories accomplish formula [15].

In the example, formula [15] implies that VTS $=\mathrm{DT}=600$. The six theories are: Modigliani-Miller, Myers, Fernandez 13, Fernandez 14, Fernandez 15 and Fernandez 16.

\section{Table 3}

Perpetuity. Value of Tax Shields (VTS) According to the 23 Theories

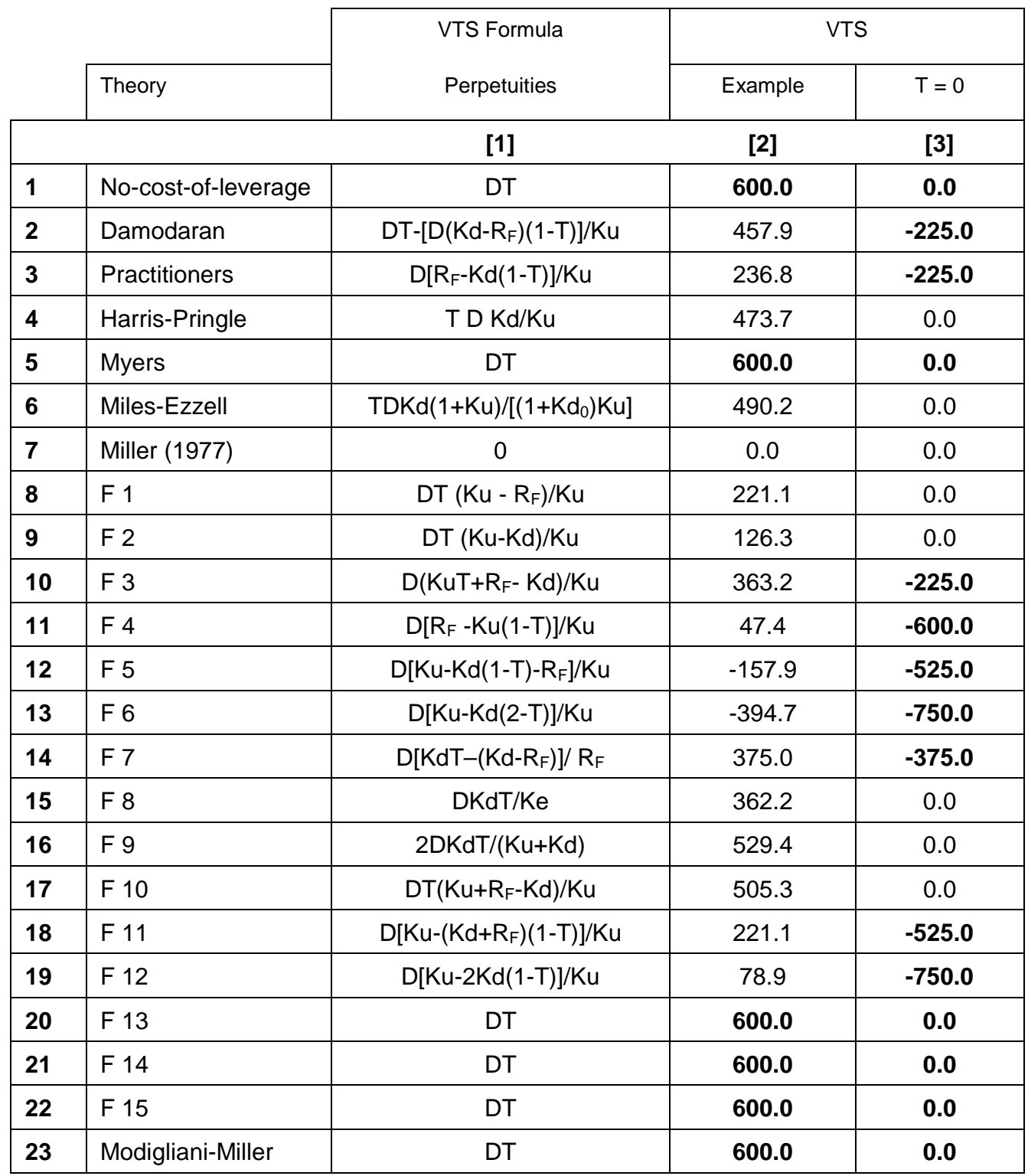




\section{For Growing Companies, the No-Costs-Of-Leverage Theory is the Right One Without Leverage Costs. VTS = D T Ku / $(\mathrm{Ku}-\mathrm{g})$}

The formula for the adjusted present value [11] indicates that the value of the debt today (D) plus that of the equity (E) of the leveraged company is equal to the value of the equity of the unleveraged company $(\mathrm{Vu})$ plus the value of tax shields due to interest payments (VTS).

$$
\text { [11] } \mathrm{E}+\mathrm{D}=\mathrm{Vu}+\mathrm{VTS}
$$

VTS (value of tax shield) is the term used to define the increase in the company's value as a result of the tax saving obtained by the payment of interest. $\mathrm{Vu}=\mathrm{FCF} /(\mathrm{Ku}-\mathrm{g})$. $\mathrm{g}$ is the growth rate.

As we ponted out in the previous section, the value of tax shields (VTS) is the difference between the PV of the taxes paid in the unleveraged company $(\mathrm{Gu})$ and the PV of the taxes paid in the leveraged company $\left(\mathrm{G}_{\mathrm{L}}\right)$.

For a growing perpetuity, we cannot give a clear answer about the required return on taxes as we have done for perpetuities.

Equation [26] means that the total value of the unleveraged company (left hand side of the equation) is equal to the total value of the leveraged company (right hand side of the equation). Total value is the enterprise value (often called value of the firm) plus the present value of taxes. Vu is the value of the unleveraged company. $\mathrm{Gu}$ is the present value of the taxes paid by the unleveraged company. E is the equity value and D is the debt value. GL is the present value of the taxes paid by the leveraged company.

$$
\mathrm{Vu}_{\mathrm{t}}+\mathrm{Gu}_{\mathrm{t}}=\mathrm{E}_{\mathrm{t}}+\mathrm{D}_{\mathrm{t}}+\mathrm{GL}_{\mathrm{t}}
$$

The value of tax shields (VTS) is:

$$
\mathrm{VTS}_{\mathrm{t}}=\mathrm{Gu}_{\mathrm{t}}-\mathrm{GL}_{\mathrm{t}}
$$

For the unleveraged company, the relationship between taxes and free cash flow is different from that obtained for perpetuities:

TaxesU $=\mathrm{T}[\mathrm{FCF}+\mathrm{g}(\mathrm{WCR}+\mathrm{NFA})] /(1-\mathrm{T})=\mathrm{T}[\mathrm{FCF}+\mathrm{g}(\mathrm{Ebv}+\mathrm{D})] /(1-\mathrm{T})$

WCR is the net working capital requirements. NFA is the net fixed assets. Ebv is the equity book value. $\mathrm{g}$ is the constant growth rate.

From equation [28] we cannot establish a clear relationship between the required return on taxes and the required return on assets $(\mathrm{Ku})$ as we did for perpetuities in equation [18].

The present value of taxes in the unleveraged company is:

$$
\mathrm{Gu}=\operatorname{Taxes}_{\mathrm{U}} /\left(\mathrm{K}_{\mathrm{TU}}-\mathrm{g}\right)
$$

In a leveraged company with constant growth, the relationship between taxes and equity cash flow is different from that obtained for perpetuities:

$$
\text { TaxesL }=\mathrm{T}(\mathrm{ECF}+\mathrm{g} \text { Ebv) } /(1-\mathrm{T})
$$

From equation [30] we cannot establish a clear relationship between the required return on taxes and the required return on equity as we did for perpetuities in equation [21]. 
The present value of taxes in the leveraged company is:

$$
\mathrm{G}_{\mathrm{L}}=\operatorname{Taxes}_{\mathrm{L}} /\left(\mathrm{K}_{\mathrm{TL}}-\mathrm{g}\right)
$$

The increase in the value of the company due to the use of debt is not the present value of the tax shield due to the payment of interest but the difference between Gu and GL, which are the present values of two cash flows with a different risk:

$$
\text { VTSt }=\text { Gut }- \text { GLt }=[\text { TaxesU } /(\text { KTU -g) }]-[\text { TaxesL } /(\text { KTL }-\mathrm{g})]
$$

The relationship between $\operatorname{Taxes}_{\mathrm{U}}$ and $\mathrm{Taxes}_{\mathrm{L}}$ is:

$$
\operatorname{Taxes}_{U t+1}-\operatorname{Taxes}_{\mathrm{L} t+1}=\mathrm{D}_{\mathrm{t}} \mathrm{Kd} \mathrm{T}
$$

For perpetuities, and only for perpetuities, it can be argued that the risk of this difference is $\mathrm{Kd}$. Therefore, the present value of this difference should be $\mathrm{Kd} \mathrm{T} \mathrm{D} \mathrm{/} \mathrm{Kd} \mathrm{=} \mathrm{T} \mathrm{D.} \mathrm{But} \mathrm{in} \mathrm{the} \mathrm{following}$ lines it will be seen that for growing companies the risk of the interest tax shield is not $\mathrm{Kd}$.

According to No-cost-of-leverage, the VTS is the present value of D T Ku (not the interest tax shield) discounted at the unleveraged cost of equity $(\mathrm{Ku})$ :

$$
\mathrm{PV}[\mathrm{Ku} ; \mathrm{D} \mathrm{T} \mathrm{Ku}]
$$

Now, we deduct equation [34].

The relationship between the equity cash flow and the free cash flow is

$$
\mathrm{FCF}=\mathrm{ECF}+\mathrm{D} \mathrm{Kd}(1-\mathrm{T})-\mathrm{g} \mathrm{D}
$$

The relationship between the value of the equity of the unleveraged firm and the free cash flow is

$$
\mathrm{Vu}=\mathrm{FCF} /(\mathrm{Ku}-\mathrm{g})
$$

By substituting [35] and [36] in [11], we get:

$$
\mathrm{E}+\mathrm{D}=[\mathrm{ECF}+\mathrm{D} \mathrm{Kd}(1-\mathrm{T})-\mathrm{g} \mathrm{D}] /(\mathrm{Ku}-\mathrm{g})+\mathrm{VTS}
$$

The relationship between the equity cash flow and the equity value is

$$
\mathrm{ECF}=\mathrm{E}(\mathrm{Ke}-\mathrm{g})
$$

By substituting [38] in [37], we get:

$$
\mathrm{E}+\mathrm{D}=[\mathrm{E}(\mathrm{Ke}-\mathrm{g})+\mathrm{D} \mathrm{Kd}(1-\mathrm{T})-\mathrm{g} \mathrm{D}] /(\mathrm{Ku}-\mathrm{g})+\mathrm{VTS}
$$

Multiplying both sides of equation [39] by $(\mathrm{Ku}-\mathrm{g})$ we get:

$$
(\mathrm{E}+\mathrm{D})(\mathrm{Ku}-\mathrm{g})=[\mathrm{E}(\mathrm{Ke}-\mathrm{g})+\mathrm{D} \mathrm{Kd}(1-\mathrm{T})-\mathrm{g} \mathrm{D}]+\mathrm{VTS}(\mathrm{Ku}-\mathrm{g})
$$

Eliminating $-g(E+D)$ on both sides of the equation [40]:

$$
(\mathrm{E}+\mathrm{D}) \mathrm{Ku}=[\mathrm{E} \mathrm{Ke}+\mathrm{D} \mathrm{Kd}(1-\mathrm{T})]+\mathrm{VTS}(\mathrm{Ku}-\mathrm{g})
$$

Equation [41] may be rewritten as:

$$
\mathrm{D}[\mathrm{Ku}-\mathrm{Kd}(1-\mathrm{T})]-\mathrm{E}(\mathrm{Ke}-\mathrm{Ku})=\mathrm{VTS}(\mathrm{Ku}-\mathrm{g})
$$


Equation [42] also has to hold when the company is all-debt financed, that is, when $\mathrm{E}=0$ and ECF $=0$ (the equity cash flow is zero). In this extreme situation, the whole risk of the assets is borne by the debt $(\mathrm{Kd}=\mathrm{Ku})$, and equation [42] is:

$$
\mathrm{D}[\mathrm{Ku}-\mathrm{Ku}(1-\mathrm{T})]=\operatorname{VTS}(\mathrm{Ku}-\mathrm{g})
$$

Note that [43] is the same as equation [34]:

$$
\mathrm{VTS}=\mathrm{D} \mathrm{T} \mathrm{Ku} /(\mathrm{Ku}-\mathrm{g})
$$

Dividing both sides of equation [42] by D (debt value), we get:

$$
[\mathrm{Ku}-\mathrm{Kd}(1-\mathrm{T})]-(\mathrm{E} / \mathrm{D})(\mathrm{Ke}-\mathrm{Ku})=(\mathrm{VTS} / \mathrm{D})(\mathrm{Ku}-\mathrm{g})
$$

If (E / D) is constant, the left-hand side of equation [44] does not depend on growth (g) because for any growth rate (E / D) $(\mathrm{Ke}-\mathrm{Ku}), \mathrm{Ku}$ and $\mathrm{Kd}$ are constant. We know that for $\mathrm{g}=0$, VTS $=\mathrm{DT}$ (equation [25]). Then, equation [44] applied to perpetuities $(g=0)$ is: $[K u-K d(1-T)]-(E / D)(K e-K u)=T ~ K u$.

Substracting it from [44] we get $0=($ VTS / D) $(\mathrm{Ku}-\mathrm{g})-\mathrm{T} \mathrm{Ku}$, which is equation [34].

One must remember that the VTS is not the PV of tax shields, but the difference between two present values of two cash flows with different risks: the PV of the taxes of the unleveraged company and the PV of the taxes of the leveraged company.

Equations [34] is valid if the cost of debt $(r)$ is equal to the required return on debt (Kd). In this situation, the value of the debt (D) is equal to the nominal or book value of the debt (N). Fernandez (2002a) contains the formulas when the value of the debt (D) is not equal to the nominal or book value of the debt $(\mathrm{N})$. In particular, he proves that equation [34] changes into:

$$
\mathrm{VTS}=[\mathrm{D} \mathrm{T} \mathrm{Ku}+\mathrm{T}(\mathrm{N} \mathrm{r}-\mathrm{D} \mathrm{Kd})] /(\mathrm{Ku}-\mathrm{g})
$$

Fernandez (2002a) also proves that the weighted average cost of capital (WACC) is:

$$
\mathrm{WACC}=\frac{\mathrm{E} \mathrm{Ke}+\mathrm{D} \mathrm{Kd}-\mathrm{NrT}}{\mathrm{E}+\mathrm{D}}
$$

We have proved that the No-cost-of-leverage formula is the right one for calculating the VTS in a world without leverage costs. On top of that, Table 4 shows that the alternative formulas may provide a required return on equity $(\mathrm{Ke})$ lower than the required return on assets $(\mathrm{Ku})$. 


\section{Table 4}

Problems for the Candidate Formulas in Calculating the VTS in a World Without Leverage Costs with Constant Growth

\begin{tabular}{|l|l|}
\cline { 2 - 2 } \multicolumn{1}{l|}{} & $\mathrm{Ke}<\mathrm{Ku}$ \\
\hline No-cost-of-leverage & Never \\
\hline Myers & If $\mathrm{g}>\mathrm{Kd}(1-\mathrm{T})$ \\
\hline F 13 & If $\mathrm{D}(1-\mathrm{T})>\mathrm{Vu}$ \\
\hline F 14 & If Ku $(\mathrm{Vu}-\mathrm{E} \mathrm{T})<\mathrm{Kd}(1-\mathrm{T})(\mathrm{Vu}+\mathrm{D} \mathrm{T})$ \\
\hline F 15 & If $\mathrm{Vu}<\mathrm{E} \mathrm{T}$ \\
\hline Modigliani-Miller & $\begin{array}{l}\text { If TRF }(\mathrm{Ku}-\mathrm{g}) /\left(\mathrm{R}_{\mathrm{F}}-\mathrm{g}\right)>\mathrm{Ku}-\mathrm{Kd}(1-\mathrm{T}) \\
\text { If } \mathrm{VTS}>\mathrm{D}[\mathrm{Ku}-\mathrm{Kd}(1-\mathrm{T})] /(\mathrm{Ku}-\mathrm{g})\end{array}$ \\
\hline
\end{tabular}

On top of that, according to Myers, F 14, F 15 and Modigliani-Miller, Ke decreases when T (tax rate) increases. According to No-cost-of-leverage and F 13, Ke increases when T increases.

Tables 5 and 6 provide us a sensitivity analysis of the six theories. The example used is that of section 5 with constant growth. We may see that the five theories mentioned (all except the Nocost-of-leverage) in some circumstances provide values of the required return on equity (Ke) lower than the required return on assets $(\mathrm{Ku})$.

\section{Table 5}

Six Candidate Theories to Measure the VTS in a World Without Leverage Costs

$\mathrm{Ku}=20 \%$. Unleveraged beta $=1$; Risk-free rate $=12.0 \%$; Market risk premium $=8.0 \% ; \mathrm{Kd}=15.0 \%$; $\mathrm{g}$ (growth) $=8.0 \%$

\begin{tabular}{|c|c|c|c|c|c|c|c|c|c|}
\hline \multirow[b]{2}{*}{$\mathrm{Ke}$} & \multicolumn{9}{|c|}{ Tax rate } \\
\hline & $0 \%$ & $20 \%$ & $30 \%$ & $40 \%$ & $50 \%$ & $60 \%$ & $65 \%$ & $70 \%$ & $80 \%$ \\
\hline No-cost-of-leverage & $22.10 \%$ & $22.15 \%$ & $22.19 \%$ & $22.24 \%$ & $22.32 \%$ & $22.45 \%$ & $22.56 \%$ & $22.71 \%$ & $23.41 \%$ \\
\hline Myers & $22.10 \%$ & $21.75 \%$ & $21.50 \%$ & $21.16 \%$ & $20.70 \%$ & $20.00 \%$ & $19.50 \%$ & $18.84 \%$ & $16.56 \%$ \\
\hline F 13 & $22.10 \%$ & $22.26 \%$ & $22.38 \%$ & $22.57 \%$ & $22.90 \%$ & $23.58 \%$ & $24.31 \%$ & $25.90 \%$ & $-0.19 \%$ \\
\hline F 14 & $22.10 \%$ & $22.07 \%$ & $21.92 \%$ & $21.53 \%$ & $20.52 \%$ & $17.87 \%$ & $15.24 \%$ & $11.34 \%$ & $3.07 \%$ \\
\hline F 15 & $22.10 \%$ & $22.13 \%$ & $22.13 \%$ & $22.10 \%$ & $21.99 \%$ & $21.67 \%$ & $21.32 \%$ & $20.72 \%$ & $17.59 \%$ \\
\hline Modigliani-Miller & $22.10 \%$ & $21.22 \%$ & $20.62 \%$ & $19.87 \%$ & $18.90 \%$ & $17.58 \%$ & $16.73 \%$ & $15.70 \%$ & $12.80 \%$ \\
\hline $\mathrm{Ku}$ & $20.00 \%$ & $20.00 \%$ & $20.00 \%$ & $20.00 \%$ & $20.00 \%$ & $20.00 \%$ & $20.00 \%$ & $20.00 \%$ & $20.00 \%$ \\
\hline
\end{tabular}




\section{Table 6}

Six Candidate Theories to Measure the VTS in a World Without Leverage Costs

Unleveraged beta $=1$; Risk-free rate $=12.0 \% ; \mathrm{T}=70.0 \%$; Market risk premium $=8.0 \%$; g (growth) $=8.0 \% ; \mathrm{Kd}=15 \%$

\begin{tabular}{|c|c|c|c|c|c|c|c|c|}
\hline \multirow[b]{2}{*}{$\mathrm{Ke}$} & \multicolumn{8}{|c|}{ Debt in $t=0$} \\
\hline & 0 & 200 & 600 & 1,000 & 1,400 & 1,800 & 2,000 & 2,200 \\
\hline No-cost-of-leverage & $20.00 \%$ & $20.45 \%$ & $21.24 \%$ & $21.89 \%$ & $22.44 \%$ & $22.91 \%$ & $23.13 \%$ & $23.32 \%$ \\
\hline Myers & $20.00 \%$ & $19.31 \%$ & $18.38 \%$ & $17.78 \%$ & $17.36 \%$ & $17.05 \%$ & $16.93 \%$ & $16.81 \%$ \\
\hline F 13 & $20.00 \%$ & $20.53 \%$ & $22.01 \%$ & $24.59 \%$ & $30.16 \%$ & $51.15 \%$ & $132.50 \%$ & $-79.00 \%$ \\
\hline F 14 & $20.00 \%$ & $19.73 \%$ & $15.45 \%$ & $10.63 \%$ & $7.68 \%$ & $6.12 \%$ & $5.64 \%$ & $5.28 \%$ \\
\hline F 15 & $20.00 \%$ & $20.31 \%$ & $20.29 \%$ & $19.92 \%$ & $19.47 \%$ & $19.05 \%$ & $18.86 \%$ & $18.68 \%$ \\
\hline Modigliani-Miller & $20.00 \%$ & $17.71 \%$ & $15.48 \%$ & $14.38 \%$ & $13.73 \%$ & $13.30 \%$ & $13.14 \%$ & $13.00 \%$ \\
\hline $\mathrm{Ku}$ & $20.00 \%$ & $20.00 \%$ & $20.00 \%$ & $20.00 \%$ & $20.00 \%$ & $20.00 \%$ & $20.00 \%$ & $20.00 \%$ \\
\hline
\end{tabular}

\section{Analysis of Competing Theories in a World with Leverage Costs}

Obviously, an acceptable theory should provide us a required return on equity (Ke) higher than the required return on assets $(\mathrm{Ku})$. It is also obvious that the VTS in a world with leverage costs provided by the theory should be lower than the VTS in a world without leverage costs according to No-cost-of-leverage (VTSNCL). Table 7 shows that only Damodaran and F 3 provide us with acceptable formulas. Practitioners, F 5, F 6, F 7, F 11 and F 12 can be eliminated because these formulas provide, in many circumstances, a VTS that is higher than the VTS according to No-costof-leverage. $\mathrm{F} 4$ can be eliminated because it provides, in many circumstances, a negative value of equity and of VTS (VTS $<0$ if $\mathrm{R}_{\mathrm{F}}<\mathrm{Ku}[1-\mathrm{T}]$ ).

\section{Table 7}

Problems with the Candidate Formulas in Calculating the VTS in a World with Leverage Costs and with Constant Growth

\begin{tabular}{|c|c|c|c|c|}
\hline & VTS > VTSNCL & $\mathrm{Ke}<\mathrm{Ku}$ & $E<0$ & \\
\hline Damodaran & & & $F C F<D\left[\left(K u+K d-R_{F}\right)(1-T)-g\right]$ & Acceptable \\
\hline Practitioners & & & $F C F<D\left[K u+K d(1-T)-R_{F-g}\right]$ & Not acceptable \\
\hline F 3 & & & $F C F<D\left[K u(1-T)+K d-R_{F^{-}} g\right]$ & Acceptable \\
\hline F 4 & & If $E<0$ & $F C F<D\left[K u(2-T)-R_{F}-g\right]$ & Not acceptable \\
\hline F 5 & when $(K u-K d)(1-T)>R_{F}$ & If $E<0$ & $F C F<D\left[K d(1-T)+R_{F^{-}} g\right]$ & Not acceptable \\
\hline F 6 & when $(K u-K d)(1-T)>K d$ & If $E<0$ & $F C F<D[K d(2-T)-g]$ & Not acceptable \\
\hline F 7 & 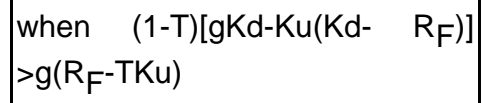 & If $g>K d(1-T)$ & $F C F<D[K d(1-T)-g](K u-g) /\left(R_{F-g}\right)$ & Not acceptable \\
\hline F 11 & when $\mathrm{Ku}>\mathrm{Kd}+\mathrm{R}_{\mathrm{F}}$ & & $\mathrm{FCF}<\mathrm{D}\left[\left(\mathrm{Kd}+\mathrm{R}_{\mathrm{F}}\right)(1-\mathrm{T})-\mathrm{g}\right]$ & Not acceptable \\
\hline F 12 & when $\mathrm{Ku}>2 \mathrm{Kd}$ & & $\mathrm{FCF}<\mathrm{D}[2 \mathrm{Kd}(1-\mathrm{T})-\mathrm{g}]$ & Not acceptable \\
\hline
\end{tabular}


Tables 8 and 9 provide us with a sensitivity analysis of the theories. The example used is that from section 5, with constant growth. We can see that the seven theories mentioned (all except Damodaran and F3) provide, in some circumstances, values of the required return on equity (Ke) lower than the required return on assets $(\mathrm{Ku})$.

\section{Table 8}

Five Candidate Theories for Measuring VTS in a World with Leverage Costs

Unleveraged beta $=1$; Risk-free rate $=12.0 \%$; Market risk premium $=8.0 \%$; (growth) $=8.0 \% ; \mathrm{Kd}=15 \%$

\begin{tabular}{|c|c|c|c|c|c|c|c|c|c|c|}
\hline \multirow[b]{2}{*}{$\mathrm{Ke}$} & \multicolumn{10}{|c|}{ Tax rate } \\
\hline & $0 \%$ & $10 \%$ & $20 \%$ & $30 \%$ & $40 \%$ & $50 \%$ & $60 \%$ & $70 \%$ & $75 \%$ & $80 \%$ \\
\hline No-cost-of-leverage & $21.80 \%$ & $21.83 \%$ & $21.86 \%$ & $21.90 \%$ & $21.97 \%$ & $22.06 \%$ & $22.23 \%$ & $22.57 \%$ & $22.92 \%$ & $23.69 \%$ \\
\hline Damodaran & $23.16 \%$ & $23.22 \%$ & $23.28 \%$ & $23.37 \%$ & $23.49 \%$ & $23.68 \%$ & $24.01 \%$ & $24.71 \%$ & $25.48 \%$ & $27.24 \%$ \\
\hline Practitioners & $23.16 \%$ & $23.68 \%$ & $24.40 \%$ & $25.47 \%$ & $27.22 \%$ & $30.63 \%$ & $40.11 \%$ & $207.01 \%$ & $-39.38 \%$ & $-5.62 \%$ \\
\hline F 3 & $23.16 \%$ & $23.39 \%$ & $23.68 \%$ & $24.09 \%$ & $24.71 \%$ & $25.72 \%$ & $27.72 \%$ & $33.46 \%$ & $43.91 \%$ & $209.47 \%$ \\
\hline $\mathrm{F} 4 . \mathrm{Ke}<0$ & $26.16 \%$ & $26.95 \%$ & $28.08 \%$ & $29.82 \%$ & $32.82 \%$ & $39.29 \%$ & $63.27 \%$ & $-95.54 \%$ & $-18.72 \%$ & $-2.75 \%$ \\
\hline F $5 . \mathrm{Ke}<0<\mathrm{Ku}$ & $25.47 \%$ & $26.52 \%$ & $28.08 \%$ & $30.62 \%$ & $35.49 \%$ & $48.61 \%$ & $206.21 \%$ & $-21.30 \%$ & $-5.64 \%$ & $1.41 \%$ \\
\hline F $6 . \mathrm{Ke}<0$ & $27.71 \%$ & $29.44 \%$ & $32.15 \%$ & $37.06 \%$ & $48.60 \%$ & $108.52 \%$ & $-60.84 \%$ & $-7.75 \%$ & $-0.89 \%$ & $3.25 \%$ \\
\hline $\mathrm{F} 7 . \mathrm{Ke}<\mathrm{Ku}$ & $26.90 \%$ & $25.72 \%$ & $24.40 \%$ & $22.92 \%$ & $21.24 \%$ & $19.33 \%$ & $17.14 \%$ & $14.59 \%$ & $13.15 \%$ & $11.58 \%$ \\
\hline F 11 & $25.47 \%$ & $25.57 \%$ & $25.70 \%$ & $25.88 \%$ & $26.13 \%$ & $26.53 \%$ & $27.22 \%$ & $28.79 \%$ & $30.64 \%$ & $35.54 \%$ \\
\hline F 12 & $27.71 \%$ & $27.87 \%$ & $28.08 \%$ & $28.37 \%$ & $28.79 \%$ & $29.44 \%$ & $30.63 \%$ & $33.46 \%$ & $37.09 \%$ & $48.72 \%$ \\
\hline $\mathrm{Ku}$ & $20.00 \%$ & $20.00 \%$ & $20.00 \%$ & $20.00 \%$ & $20.00 \%$ & $20.00 \%$ & $20.00 \%$ & $20.00 \%$ & $20.00 \%$ & $20.00 \%$ \\
\hline
\end{tabular}

\section{Table 9}

Four Candidate Theories for Measuring VTS in a World with Leverage Costs

Risk-free rate $=12.0 \% ; \mathrm{T}=40.0 \%$; Market risk premium $=8.0 \% ;$ g (growth) $=9.0 \% ; \mathrm{Kd}=15 \%$

\begin{tabular}{|c|c|c|c|c|c|c|c|c|c|}
\hline \multirow[b]{2}{*}{ Ke } & \multicolumn{9}{|c|}{ Unleveraged beta } \\
\hline & 0.50 & 0.75 & 1.00 & 1.25 & 1.50 & 1.75 & 2.00 & 2.50 & 3.00 \\
\hline No-cost-of-leverage & $16.21 \%$ & $18.84 \%$ & $21.83 \%$ & $25.23 \%$ & $29.17 \%$ & $33.75 \%$ & $39.16 \%$ & $53.56 \%$ & $76.12 \%$ \\
\hline Damodaran & $16.90 \%$ & $19.85 \%$ & $23.24 \%$ & $27.17 \%$ & $31.78 \%$ & $37.26 \%$ & $43.89 \%$ & $62.40 \%$ & $94.20 \%$ \\
\hline Practitioners. Ke $<0$ & $17.64 \%$ & $21.58 \%$ & $26.73 \%$ & $33.73 \%$ & $43.82 \%$ & $59.62 \%$ & $87.84 \%$ & $457.93 \%$ & $-185.9 \%$ \\
\hline F 3 & $17.44 \%$ & $20.65 \%$ & $24.38 \%$ & $28.74 \%$ & $33.94 \%$ & $40.22 \%$ & $47.96 \%$ & $70.53 \%$ & $112.86 \%$ \\
\hline $\mathrm{F} 4 . \mathrm{Ke}<0$ & $17.95 \%$ & $23.29 \%$ & $32.00 \%$ & $48.83 \%$ & $94.92 \%$ & $755.58 \%$ & $-138.2 \%$ & $-44.16 \%$ & $-27.67 \%$ \\
\hline $\mathrm{F} 5 . \mathrm{Ke}<\mathrm{Ke}_{\mathrm{NCL}}$ & $25.25 \%$ & $29.89 \%$ & $34.54 \%$ & $39.18 \%$ & $43.82 \%$ & $48.47 \%$ & $53.11 \%$ & $62.40 \%$ & $71.68 \%$ \\
\hline F 6 & $33.27 \%$ & $40.20 \%$ & $47.14 \%$ & $54.07 \%$ & $61.01 \%$ & $67.94 \%$ & $74.88 \%$ & $88.74 \%$ & $102.61 \%$ \\
\hline $\mathrm{F}$ 7. $\mathrm{Ke}=\mathrm{Ku}<\mathrm{Ke}_{\mathrm{NCL}}$ & $16.00 \%$ & $18.00 \%$ & $20.00 \%$ & $22.00 \%$ & $24.00 \%$ & $26.00 \%$ & $28.00 \%$ & $32.00 \%$ & $36.00 \%$ \\
\hline $\mathrm{F}$ 11. $\mathrm{Ke}<\mathrm{Ke}_{\mathrm{NCL}}$ & $19.63 \%$ & $22.67 \%$ & $25.71 \%$ & $28.74 \%$ & $31.78 \%$ & $34.82 \%$ & $37.86 \%$ & $43.93 \%$ & $50.01 \%$ \\
\hline $\mathrm{F}$ 12. $\mathrm{Ke}<\mathrm{Ke}_{\mathrm{NCL}}$ & $21.22 \%$ & $24.71 \%$ & $28.20 \%$ & $31.69 \%$ & $35.18 \%$ & $38.67 \%$ & $42.16 \%$ & $49.14 \%$ & $56.12 \%$ \\
\hline $\mathrm{Ku}$ & $16.00 \%$ & $18.00 \%$ & $20.00 \%$ & $22.00 \%$ & $24.00 \%$ & $26.00 \%$ & $28.00 \%$ & $32.00 \%$ & $36.00 \%$ \\
\hline
\end{tabular}




\section{Valuation of Companies by Discounted Cash Flow. The General Case}

When we value a hypothetical company following all 23 theories, we find that the varying results are remarkable. The equity value ranges from -869.2 to $2,933.1$. The VTS ranges from -573.4 to 3,228.9.

\section{Table 10}

Projections of Balance Sheets and Income Statements. Growth After Period 3: 10\%

\begin{tabular}{|c|c|c|c|c|c|c|}
\hline Balance Sheet & 0 & 1 & 2 & 3 & 4 & 5 \\
\hline WCR (net current assets) & 700 & 1,145 & 1,314 & 1,300 & $1,430.00$ & $1,573.00$ \\
\hline Gross fixed assets & 1,600 & 2,500 & 3,000 & 3,200 & $3,898.00$ & $4,665.80$ \\
\hline - accum. depreciation & & 200 & 620 & 1,060 & $1,544.00$ & $2,076.40$ \\
\hline Net fixed assets & 1,600 & 2,300 & 2,380 & 2,140 & $2,354.00$ & $2,589.40$ \\
\hline TOTAL ASSETS & 2,300 & 3,445 & 3,694 & 3,440 & 3,784 & 4,162 \\
\hline Debt $(\mathrm{N})$ & 1,500 & 2,300 & 2,300 & 1,755 & $1,930.50$ & $2,123.55$ \\
\hline Capital (book value) & 800 & 1,145 & 1,394 & 1,685 & $1,853.50$ & $2,038.85$ \\
\hline TOTAL LIABILITIES & 2,300 & 3,445 & 3,694 & 3,440 & 3,784 & 4,162 \\
\hline \multicolumn{7}{|l|}{ Income statement } \\
\hline Sales & & 2,700 & 3,000 & 3,200 & $3,520.00$ & $3,872.00$ \\
\hline Cost of sales & & 1,200 & 1,300 & 1,400 & $1,540.00$ & $1,694.00$ \\
\hline$G \& A$ & & 500 & 520 & 530 & 583.00 & 641.30 \\
\hline Depreciation & & 200 & 420 & 440 & 484.00 & 532.40 \\
\hline Margin & & 800 & 760 & 830 & 913 & 1,004 \\
\hline Interest payments & & 225 & 345 & 345 & 263.25 & 290 \\
\hline EBT & & 575 & 415 & 485 & 650 & 715 \\
\hline Taxes & & 230 & 166 & 194 & 259.90 & 285.89 \\
\hline EAT (net income) & & 345.00 & 249.00 & 291.00 & 389.85 & 428.84 \\
\hline + Depreciation & & 200 & 420 & 440 & 484.00 & 532.40 \\
\hline+ Increase of debt & & 800 & 0 & -545 & 175.50 & 193.05 \\
\hline - Increase of WCR & & -445 & -169 & 14 & -130 & -143 \\
\hline - Investment in fixed assets & & -900 & -500 & -200 & -698.00 & -767.80 \\
\hline Equity cash flow & & 0 & 0 & 0 & 221.35 & 243.49 \\
\hline FCF & & -665 & 207 & 752 & 203.80 & 224.18 \\
\hline CFd & & -575 & 345 & 890 & 87.75 & 96.52 \\
\hline CCF & & -575 & 345 & 890 & 309.10 & 340.01 \\
\hline
\end{tabular}




\section{Table 11}

Valuation of the Company in Table 10 According to the 23 Theories

$\mathrm{R}_{\mathrm{F}}=12 \% ; \mathrm{Ku}=20 \% ; \mathrm{Kd}=15 \%$.

\begin{tabular}{|l|r|r|r|}
\hline Value in $\mathbf{t}=\mathbf{0}$ & $\mathbf{E}$ (Equity value) & $\mathbf{V T S}$ & Ke in $\mathbf{t = 1}$ \\
\hline No-cost-of-leverage & 850.9 & $1,146.8$ & $25.3 \%$ \\
\hline Modigliani-Miller & $2,933.1$ & $3,228.9$ & $\mathbf{1 4 . 4} \%$ \\
\hline F 14 & $1,414.0$ & $1,709.8$ & $\mathbf{1 8 . 0} \%$ \\
\hline Myers & $1,362.2$ & $1,658.1$ & $\mathbf{1 9 . 4} \%$ \\
\hline F 15 & 927.7 & $1,223.6$ & $23.7 \%$ \\
\hline F 13 & 649.4 & 945.2 & $34.8 \%$ \\
\hline F 7 & $1,722.2$ & $2,018.1$ & $\mathbf{1 7 . 6 \%}$ \\
\hline F 9 & 831.3 & $1,127.1$ & $25.6 \%$ \\
\hline F 10 & 678.9 & 974.7 & $29.3 \%$ \\
\hline Miles-Ezzell & 601.6 & 897.5 & $31.8 \%$ \\
\hline Damodaran & 592.9 & 888.7 & $32.1 \%$ \\
\hline Harris-Pringle & 564.2 & 860.1 & $33.3 \%$ \\
\hline F 3 & 420.9 & 716.7 & $41.4 \%$ \\
\hline F 11 & 248.9 & 544.7 & $63.4 \%$ \\
\hline F 8 & 165.3 & 461.2 & $\mathbf{- 5 . 4 \%}$ \\
\hline F 1 & 162.9 & 458.7 & $91.8 \%$ \\
\hline Practitioners & 134.2 & 430.0 & $\mathbf{1 0 9 . 4 \%}$ \\
\hline F 2 & -9.1 & 286.7 & $\mathbf{- 1 4 5 6 . 5 \%}$ \\
\hline F 12 & -9.1 & 286.7 & $\mathbf{- 1 4 5 6 . 5 \%}$ \\
\hline Miller & -295.8 & 0.0 & $\mathbf{- 3 5 . 8 \%}$ \\
\hline F 4 & -295.8 & 0.0 & $\mathbf{- 3 5 . 8 \%}$ \\
\hline F 5 & -439.2 & -143.3 & $\mathbf{- 2 1 . 0 \%}$ \\
\hline F 6 & -869.2 & -573.4 & $\mathbf{- 5 . 9} \%$ \\
\hline Vu & $1,204.2$ & & $20.0 \%$ \\
\hline & & & \\
\hline
\end{tabular}

\section{Conclusions}

First, following a new method, we have proved that the value of tax shields for perpetuities in a world without costs of leverage is DT. The result we got is the same as in Modigliani-Miller (1963), but the reasoning behind it and the implications involved are quite different. The increase in the company's value due to the use of debt is not the present value of the tax shield due to interest payments. It is the difference between the present value of the taxes of the unleveraged company and the present value of the taxes of the leveraged company, which are the present values of two separate cash flows each with their own risks. The issue of the risks implied by the taxes for both the unleveraged and the leveraged company is addressed. We prove that, in perpetuities, the required return on tax in the unleveraged company is equal to the required return on equity in the unleveraged company. It is also proven that the required return on tax in the leveraged company is equal to the required return on equity. 
Second, we have analyzed 23 theories about the increase in the company's value due to the use of debt.

By analyzing perpetuities, we could eliminate eight theories that neither provide us with a value of the tax shield of DT (as the candidates for a world with no leverage costs should), nor provide us with a negative VTS when there are no taxes (as the candidates for a world with leverage costs should). The eight candidates eliminated due to a lack of consistent results are the following: Harris-Pringle (1985) or Ruback (1995), Miles-Ezzell (1980), F 1, F 2, F 8, F 9, F 10, and Miller (1977).

By analyzing constant growth companies, we are able to see there is but one theory that provides consistent results in a world without leverage costs. In accordance with this theory (the No-costsof-leverage), the VTS is the present value of $\mathrm{D} \mathrm{T} \mathrm{Ku}$ discounted at the unleveraged cost of equity $(\mathrm{Ku})$. It is not the interest tax shield that is discounted. VTS $=\mathrm{PV}[\mathrm{Ku}$; D T Ku]. This theory implies that the relationship between the leveraged beta and the unleveraged beta is $\beta_{\mathrm{L}}=\beta u+(\mathrm{D} / \mathrm{E})(1-$ T) $(\beta u-\beta d)$.

We find two theories that provide consistent results in a world with leverage costs, but both introduce leverage costs in an ad hoc way. The finance literature tells us very little about how to calculate costs of leverage and how the magnitude of debt, the type of debt, taxes and other factors influence them. There is a need for further research on this area.

Third, we have valued a company following all 23 theories and the varying results are remarkable. 


\section{APPENDIX 1}

Glossary

$\beta d=$ Beta of debt

$\beta_{\mathrm{L}}=$ Beta of leveraged equity

$\beta u=$ Beta of unleveraged equity $=$ beta of assets

$\mathrm{CFd}=$ Debt cash flow

$\mathrm{D}=$ Value of debt

$\mathrm{E}=$ Value of equity

$\mathrm{ECF}=$ Equity cash flow

$\mathrm{FCF}=$ Free cash flow

$\mathrm{G}_{\mathrm{L}}=\mathrm{PV}$ of Taxes $\mathrm{L}_{\mathrm{L}}=$ portion of the value of the leveraged company that belongs to the government

$\mathrm{Gu}=\mathrm{PV}$ of $\operatorname{Taxes}_{\mathrm{U}}=$ portion of the value of the unleveraged company that belongs to the government

$\mathrm{I}=$ Interest paid

$\mathrm{Ku}=$ Cost of unleveraged equity (required return on unleveraged equity)

$\mathrm{Ke}=$ Cost of leveraged equity (required return on leveraged equity)

$\mathrm{Kd}=$ Required return on debt $=$ cost of debt

$\mathrm{K}_{\mathrm{TL}}=$ Appropriate discount rate for tax flow of leveraged firm

$\mathrm{K}_{\mathrm{TU}}=$ Appropriate discount rate for tax flow of unleveraged firm

$\mathrm{Nt}=$ Nominal amount of debt repaid in year $\mathrm{t}$

$\mathrm{P}_{\mathrm{M}}=$ Market premium $=\mathrm{E}\left(\mathrm{R}_{\mathrm{M}}-\mathrm{R}_{\mathrm{F}}\right)$

$\mathrm{PV}=$ Present value

$\mathrm{R}_{\mathrm{F}}=$ Risk free rate

$\mathrm{T}=$ Corporate tax rate

Taxes $_{U}=$ Taxes paid by the unleveraged company

$\operatorname{Taxes}_{\mathrm{L}}=$ Taxes paid by the leveraged company

$\mathrm{Vu}=$ Value of shares in the unleveraged company

WACC $=$ Weighted average cost of capital

$\mathrm{WACC}_{\mathrm{BT}}=$ Weighted average cost of capital before taxes. This is the appropriate discount rate for the capital cash flow (sum of the equity cash flow and debt cash flow). 


\section{REFERENCES}

Arditti, F. D. and H. Levy (1977), "The Weighted Average Cost of Capital as a Cutoff Rate: A Critical Examination of the Classical Textbook Weighted Average,” Financial Management (Fall), pp. 24-34.

Copeland, T. E., T. Koller and J. Murrin (2000), Valuation: Measuring and Managing the Value of Companies, Third edition, John Wiley and Sons, New York.

Damodaran, A (1994), “Damodaran on Valuation,” John Wiley and Sons, New York.

Fernandez, Pablo (2001a), "The Value of Tax Shields is NOT Equal to the Present Value of Tax Shields," SSRN Working Paper no. 290727.

Fernandez, Pablo (2001b), "Valuing Companies by Cash Flow Discounting: Eight Methods and Six Theories,” SSRN Working Paper, no. 256987.

Fernandez, Pablo (2002), Valuation Methods and Shareholder Value Creation, Academic Press Publishers.

Harris, R.S. and J.J. Pringle (1985), "Risk-Adjusted Discount Rates Extensions form the AverageRisk Case,” Journal of Financial Research (Fall), pp. 237-244.

Kaplan, S. and R. Ruback (1995), "The Valuation of Cash Flow Forecast: An Empirical Analysis," Journal of Finance, Vol. 50 No 4, September.

Lewellen, W.G. and D.R. Emery (1986), "Corporate Debt Management and the Value of the Firm," Journal of Financial Quantitative Analysis, (December), pg. 415-426.

Luehrman, Timothy A (1997), "What's Worth: A General Manager's Guide to Valuation," and "Using APV: A Better Tool for Valuing Operations,” Harvard Business Review, (May-June), pp. 132-154.

Miles, J.A. and J.R. Ezzell, (1980) "The Weighted Average Cost of Capital, Perfect Capital Markets and Project Life: A Clarification," Journal of Financial and Quantitative Analysis (September), pp. 719-730.

Miles, J.A. and J.R. Ezzell, (1985) "Reformulating Tax Shield Valuation: A Note," Journal of Finance Vol. XL, 5 (December), pp. 1485-1492.

Miller, M.H. (1977), “Debt and Taxes,” Journal of Finance (May), pg. 261-276.

Modigliani, F., and M. Miller, (1958), "The Cost of Capital, Corporation Finance and the Theory of Investment," American Economic Review 48, 261-297.

Modigliani, F and M. Miller (1963), “Corporate Income Taxes and the Cost of Capital: A Correction,” American Economic Review (June), pp. 433-443.

Myers, S.C. (1974), "Interactions of Corporate Financing and Investment Decisions - Implications for Capital Budgeting,” Journal of Finance (March), pp. 1-25 
Ruback, Richard S. (1995), A Note on Capital Cash Flow Valuation, Harvard Business School, 9295-069.

Taggart, R.A. Jr (1991), "Consistent Valuation and Cost of Capital. Expressions With Corporate and Personal Taxes,” Financial Management (Autumn), pg. 8-20.

Tham, Joseph, and Ignacio Vélez-Pareja (2001), "The correct discount rate for the tax shield: the Nperiod case," SSRN Working Paper. 